\title{
TENSES UNDERSTANDING IN USING THE ENGLISH LANGUAGE
}

\author{
${ }^{1}$ Martina Napratilora, ${ }^{2}$ Seri Yanti Siagian \\ STAI Auliaurrasyidin Tembilahan \\ E-mail: ${ }^{1}$ Napratiloramartina@gmail.com,.2Serisiagian19@gmail.com
}

\begin{abstract}
Language is one of the tools for communicating. English is one of the languages that are used to communicate. Mastering simple present tense is able to make English communicating run well, effectively, and clearly. Using the English language to communicate in daily life should comprehend about simple present tense because this tense more often to be used than other tenses for daily communication. This paper will explain how to make sentences using simple present and how to use simple present in communicating. Simple present tense refers to something happened in present time. The students will be easy to understand and use tense by knowing who the subject in the sentence is, knowing the sentence kinds, and knowing the sentence form.
\end{abstract}

Keywords: English language, Communication, Simple Present Tense.

\begin{abstract}
Abstrak
Bahasa merupakan salah satu alat untuk berkomunikasi. Bahasa Inggris merupakan salah satu bahasa yang digunakan untuk berkomunikasi. Penguasaan tenses simple present dapat membantu komunikasi dalam berbahasa Inggris berjalan dengan baik, effektip, dan jelas. Penggunaaan Bahasa Inggris untuk berkomunikasi dalam kehidupan sehari-hari harus memahami tentang tenses simple present, karena tenses ini lebih sering digunakan dari pada tenses yang lain untuk komunikasi sehari-hari. Artikel ini akan menjelaskan tentang bagaimana membuat kalimat-kalimat menggunakan tenses simple present dan bagaimana menggunakan tenses simple present dalam berkomunikasi. Tenses simple present menjelaskan tentang sesuatu atau peristiwa yang terjadi pada masa sekarang. Siswa akan mudah untuk memahami dan menggunakan tenses ini dengan mengetahui siapa subjek dalam kalimat, mengetahui jenis-jenis kalimat, dan mengatahui bentuk kalimat.
\end{abstract}

Kata Kunci: Bahasa Inggris, Komunikasi, Simpel Present Tense 


\section{INTRODUCTION}

Language is a tool to communicate with other people in the form of spoken and written. There are many languages in the world one of them is the English language. English refers to an international language. It means that many people use English to communicate with others. By mastering English will help us in communicating with other people in different countries, help us to get more knowledge, information, and literature review which is written in English. So, we can master knowledge and skills in many fields like education, science, economic, and so on.

Communicating involves four skills. They are listening, reading, speaking, and writing. Successful communication needs vocabularies mastering and English grammar like tenses. Comprehending in using the tenses will help us to use the language clearly and effectively. Therefore, tense is important to be discussed as one of the English basic to master and understand English sentences in communication and learning activities.

Mastering English language needs knowledge about tenses. Tense is one of the important components of English which is related to the time of an event occurs in the sentence. In addition, tenses refer to an important thing and basic thing to learn about English. How can we use the language, if we do not know about the language basic itself!. Without mastering it, our language will be difficult to be understood by other people especially native speakers. People are not able to use English without mastering tenses first.

Besides that, Spoken and written Communication will run well if the listeners understand what the speakers say. In written communicating, the writers write wrong sentence structure, it will make the readers confused about our message, content, and purposes in the paper. When the writer wants to tell an event that is happened in the past, but the writer writes it in present time. Using the wrong tense 
in a sentence will create confusion and misunderstanding about the messages (Geikhman, n.d.).

Besides that, the writer/speaker tells an activity (verbal), but the writer uses the nominal sentence. Many students of EFL (English as Foreign Language) fail to master tense and spend much time to master it (Rahman \& Maksud, 2015). For EFL/ESL ( English as Foreign Language/ English as a Second Language) the difficult thing in mastering English grammar is English verb-tenses (Larsen-freeman, Kuehn, \& Haccius, n.d.). Avoiding this, the speakers and writers have to understand and master tenses to make communicating run well. Understanding language aspects are very important for the users to use the language properly (Rahman \& Maksud, 2015).

One of the language aspects is grammar (tenses). Grammar is so important to convey speakers' and writers' ideas to the readers and listeners ("Using articles and tense: Improving Grammar; Focusing on

English Journal of Indragiri (EJI)
Article and Verb Use," n.d.). In addition, mastering the English language will help college students to write an English thesis and abstract. This paper will explain how to make sentences using simple present and how to use the simple present.

If people want to master English well, the people should master the tenses well too. There are many kinds of tense some of them are present tense, past tense, future tense, and perfect tense. In this paper, the writer will focus on simple present tense.

\section{FINDINGS AND DISCUSSION}

Language refers to convey idea, opinion, thinking, and feeling to other people. People are able to communicate with others by using spoken and written language. So many languages which are used by people to covey idea, opinion, thinking, and feeling, one of them is the English language. English as a foreign language in Indonesia, it means that Indonesian people do not use English for daily communication 
but it is learned in formal and informal education. Communication has closed relationship to the skills of listening, reading, speaking, and writing. Students are able to convey their ideas, opinions, thinking, and feeling effective, clearly, and efficiently by mastering tenses. Therefore, it is so important to discuss the tenses understanding in using the English language.

Tense refers to the time of an event or activity happened in a sentence. Time refers to the present, past, and future. Generally, tense use specific verbs in sentences like "study-studied-studied, go-wentgone, speak-spoke-spoken, and so on". In other word, tenses explain about the time of speaking moment. So, the speaker, writer, or language users have to consider about time context of ideas, opinion, thinking, and feeling before using the verb or to be in a sentence or statement. Tense in verbs expresses time. It is referenced to the moment of speaking (Cowan, 2008). Getting more understanding of tenses, the first most basic things that need to be understood is parts of time. The English Journal of Indragiri (EJI)
English language has three kinds of time. They are present, past, and future. In this paper will focus on the present tense.

Present tense describes an event or activity which is happened at the time or to tell things in general and to explain the repeated action or habitual. It is also used to express general facts. In addition, present tense refers to present action in the present time and it is not finished. The function of the simple present tense is to explain the present time (Huddleston \& Pullum, 2005). Present tense use to say thoughts, feelings, states, things staying the same, fact, thing that is true for a long time, repeated action, and for the future meaning of simple present (Eastwood, 1999). Besides that, simple present talk about actions that we can see as long-term or permanent (Brown \& Brown, 2010). There are several uses of simple present tense. They are (Alexander, 1990):

1. Permanent truths

Example:

A human needs food

Cat likes fish 
Summer follows spring

2. The present period

Example:

I am a student

My father works at the office

We learn English with Miss

Tina

3. Habitual action

Example:

I get up at 05.00 o'clock

She always listens to English

music

They go to school at 07.00

o'clock

4. Future reference

Example:

He stars his English course next week

We submit our homework tomorrow

You visit me next month

5. Observation and declaration

Example:

I like you

She loves me

I am success

6. Instruction

Example:

You have to go now

Open the door!

First, you stir the water and sugar

7. Commentaries

Example:

They present their paper

She does not speak English

They do not use school uniform

Present tense has its own formula with its verbs. Simply, the formula stars with the subject and followed by infinitive verb or verb by adding es/s based on who is the doer in the sentence. It means, simple present tense uses verb 1 to show the action in a verbal sentence and use to be (am, is, are) in a nominal sentence. time signal which is often used in the simple present like always, usually, often, sometimes, rarely, seldom, never, and so on. The forms of simple present sentences are (Azar, 2003):

1. Verbal sentence

The Verbal sentence
means that the sentence
predicate is a verb. In other
words, the subjects do an
activity in the sentence. the
important thing that should be
known by the user is who is the


doer in the sentence because the subject will influence verb form in simple present especially if the subject is third person singular (she, he, it) the verb is ending by $\mathrm{s}$, ss, ch, $\mathrm{o}$, and $\mathrm{x}$ the verb should get suffix es but if the verb is not ending by $\mathrm{s}$, ss, $\mathrm{ch}, \mathrm{x}$, and o the verb have to get suffix $s$ example he goes to school, she teaches me English, he works at office. The formula of a verbal sentence is:

\begin{tabular}{cc}
\hline \multicolumn{3}{c}{ Verbal Sentence } \\
\hline Subject & Verb 1 \\
\hline I & Verb 1 \\
You & Verb 1 \\
They & Verb 1 \\
We & Verb 1 \\
She & Verb 1 + es/s \\
He & Verb 1 + es/s \\
It & Verb 1 + es/s
\end{tabular}

Besides that, when the subject is a third singular person (she, he, it), the verb ending $Y$ and following by consonant we have to change $Y$ become $I$ and add suffix es. Example: she studies English, he copies the paper, she tries to speak English well.

Statement sentence (positive) is able to be changed into negative and interrogative by adding auxiliary verb (do/does) and not for a negative and auxiliary verb (do/does) for interrogative.

Example:

Statement : I work at the office

Negative: I do not work

Interrogative : do I work?

Statement: He goes to campus

Negative: He does not go to campus Interrogative: Does he go to campus? 
2. Nominal sentence

The nominal sentence means the sentence predicate is not a verb. It claims that the doer does not do an activity in the sentence. Characteristic of a nominal sentence is always uses to be (am, is, and are).

\section{Nominal Sentence}

\begin{tabular}{cc}
\hline Subject & To Be (am, is, are) \\
\hline I & am \\
You & are \\
They & are \\
We & are \\
She & Is \\
He & Is \\
It & Is
\end{tabular}

Example

Statement : I am a student

Negative : I am not a student

Interrogative : am I a student/ are you a student?

Statement : She is beautiful

Negative : She is not beautiful

Interrogative : Is she beautiful?

Statement : We are in the class

Negative: We are not in the class

Interrogative: Are we in class?

Based on the explanation above, it can be concluded that there are some ways to uses English clearly and correctly. They are:

1. Knowing who the subject in the sentence is.

Knowing the subject will help us to use and choose the correct verb or to be because the subject will influence the form of a verb and to be. Introduce the third person singular (she, he, it) which prove the most difficult for students. When the student is familiar with a third-person singular, they will be comfortable in speaking (spoken communication) (Beare, 2018). 
2. Knowing the kinds of sentence

Kind of sentences here means verbal or nominal sentence. By knowing these things, we will be easy to decide in applying the verb or to be in the sentence. The nominal sentence is describing or telling about daily activity and general truth which does not use a verb in the sentence. Verbal sentence explains about habit activity and general fact which uses the verb in the sentence (Kamil, n.d.).

3. Knowing the form of sentence

The form of the sentence here means statement/positive, negative, and interrogative sentence. The language users have to pay attention to this because different sentence form will have a different pattern. To be good language user have to use sentence form correctly.

Introduce negative and interrogative form of a simple present to make the students familiar with the sentence form. Make sure to point out the difference between yes and no questions and information questions. Star with yes/no questions to encourage students to answer in the short form and make sure to vary the subject up to help students to be familiar with drop out 's' or 'es' in a negative or interrogative sentence (Beare, 2018). It will help students feel comfortable to use the language in speaking.

In other words, introduce first person singular, second person singular, third person singular, plural person, statement, negative, and interrogative. Example: first, the teacher makes an affirmative statement and then change into negative and interrogative after that ask the students to do the same thing to practice it (Pesce, n.d.). This activity will help the students to be familiar with this sentence form.

$$
\text { However, mastering }
$$
tense is so important to support our daily communication. When we communicate in the wrong tense it creates confusion and 
misunderstanding between speaker and listener. So, making good communication needs to master tense well. If students master simple present tense. They are able to write descriptive text well (Deviga \& Widiana, 2006). By mastering 5 basic tenses are able to express thinking, feeling, idea, and opinion in English. Tenses mastering are enough for beginners to begin active communication with others (Elfitriani, Kustini, \& Kusnasari, 2014).

\section{CONCLUSION}

$$
\text { Simple present tense }
$$
something happened in present time. Students are able to use the English language by understanding the grammar (tense) of the language itself. Using the English language to communicate in daily life should comprehend about simple present tense because this tense more often to be used for daily communication. Communication will run effectively, clearly, and efficiently when the speaker/writer has to use the right tense for avoiding misunderstanding or misinterpreting the message. The students will be easy to understand and use tense by knowing who the subject in the sentence is, knowing the sentence kinds, and knowing the sentence form

\section{REFERENCES}

Alexander, G. L. (1990). Longman English Grammar Practice: for Intermediate Students. New York: Longman.

Azar, B. S. (2003). Fundamentals of English Grammar (Third Edition). America: Longman.

Beare, K. (2018). How to Teach the Present Simple. Retrieved November 23, 2018, from https://www.thoughtco.com/ho w-to-teach-the-present-simple1212226

Brown, C., \& Brown, P. (2010). English Grammar Secrets. Pearson.

Cowan, R. (2008). The Teacher's Grammar of English: A Course Book and Reference Guide. New York: Cambridge University Press.

Deviga, L., \& Widiana, Y. (2006). Korelasi antara Penguasaan Simple Present Tense dengan Menulis Paragraf Deskriptif Mahasiswa Keperawatan 
Semester 2 C. Motivation and Emotion, 30(3), 243-250.

Eastwood, J. (1999). Oxford Practice Grammar: with Answers (Second Edi). New York: Oxford University Press.

Elfitriani, Kustini, R., \& Kusnasari, S. (2014). An observation on Students ' Ability in Using 5 Basic Tenses ( Simple Present Tense, Simple Past Tense, Present Perfect Tense, Present Continuous Tense, and Present Future Tense ) for Speaking English. Journal SAINTIKOM, 13(2), 105-112. Retrieved from https://lppm.trigunadharma.ac.i d/public/fileJurnal/hp2Lhpvq3 Fitri Journal.pdf

Geikhman, Y. (n.d.). The Quick and Easy Guide to Learning English Grammar Tenses. Retrieved November 23, 2018, from https://www.fluentu.com/blog/e nglish/learn-english-grammartenses/

Huddleston, R., \& Pullum, G. K. (2005). A Student's Introduction to English Grammar. America: Cambridge University Press. https://doi.org/10.1353/lan.0.00 36

Kamil, R. (n.d.). Belajar Artikel Ilmiah: Memahami "Simple Present Tense" dalam Pendekatan Jurnal Ilmiah. https://doi.org/10.1007/s00204- 009-0425-z

Larsen-freeman, D., Kuehn, T., \& Haccius, M. (n.d.). Helping Students Make Appropriate English Verb Tense-Aspect Choices. TESOL Journal, 11(4), 3-9.

https://doi.org/10.1002/j.19493533.2002.tb00102.x

Pesce, C. (n.d.). How to Teach the Present Simple Tense. Retrieved November 23, 2018, from https://busyteacher.org/3560how-to-teach-the-presentsimple.html

Rahman, M. S., \& Maksud, A. (2015). Problems in Mastering English Tense and Aspect and the Role of the Practitioners. IOSR Journal Of Humanities And Social Science, 20(4), 131135. https://doi.org/10.9790/08372041131135

Using articles and tense: Improving Grammar; Focusing on Article and Verb Use. (n.d.). Retrieved November 21, 2018, from www.services.unimelb.edu.au/a cademicskills 